\title{
Dividend Policy and Earnings Management: An Empirical Study of Pakistani Listed Companies
}

\author{
*Ahmed Arif1, Afsheen Abrar2, Mehwish Aziz Khan³, Ferheen Kayani4 ${ }^{4}$, Syed Zulfiqar Ali Shah ${ }^{5}$ \\ ${ }^{1}$ Shaheed Zulfiqar Ali Bhutto Institute of Science and Technology, Islamabad, Pakistan \\ ${ }^{2}$ National University of Modern Languages, Islamabad, Pakistan \\ ${ }^{3}$ Federal Urdu University of Arts, Science and Technology, Islamabad, Pakistan \\ ${ }^{4}$ Comsats Institute of Information Technology, Islamabad, Pakistan \\ ${ }^{5}$ International Islamic University, Islamabad, Pakistan \\ *lakhvera@gmail.com
}

\begin{abstract}
Dividend policy is one of the widely addressed topics in financial management. It is an important duty of a financial manager to formulate the company's dividend policy that is in the best interest of the company. Many a time financial managers are involved in earnings management practices with the intention of adjusting dividends. The present study has been carried out to scrutinize the effect of earnings management on dividend policy. The researchers have taken the data of 86 listed companies for the year 2004 to 2009. The researchers have measured the dividend policy by using dividend payout ratio while Modified Cross Sectional Jones Model (1995) has been employed to measure the earnings management. The results of the common effect model show that there is not any significant relationship among earnings management and dividend policy. Moreover, smaller companies are paying more dividends as compared to larger companies. This study reveals that involvement of managers is not for dividend policy. There might be some other motives behind the earnings management.
\end{abstract}

Key words: Dividend policy, Earnings management, Discretionary accruals, Return on equity

\section{Introduction}

The explanation of dividend policy is one of the main concerns in financial management. It is an important responsibility of financial manager to devise dividend policy of the company. Despite the number of studies have been conducted on dividend policy, the factors affecting the dividend policy and outcomes of dividend policy are still required to be explored. The researchers and practitioners have still to develop a consensus in this regard. Black (1976) wrote about the dividend policy, "The harder we look at the dividend picture, the more it seems like a puzzle, with pieces that just do not fit together". Dividend signaling and capital market equilibrium can be helpful in solving the dividend puzzle. The previous studies show that the dividend announcement can be helpful in increasing the firm's value (Koch \& Shenoy, 1999; Lee \& Xiao, 2003; Guttman, Kadan \& Kandel, 2008; Hussainey \& Aal-Eisa, 2009; Fairchild, 2010). The managers are well aware about the future cash flows of the firm. They only announce the dividend if signaling benefit is greater than the associated cost (Bhattacharya, 1979).

Miller \& Modigilani's "Irrelevance Theorem" is the starting point for any discussion about dividends. This theorem states that investment policy of the firm is predetermined and irreversible. The dividend policy does not play any role in the determination of firm's value. The price of firm's equity in the market may rise proportionately with earnings. Whereas, in case of distribution of dividends, financing can be obtained by means of raising funds in capital market and the value of firm's equity may decrease proportionally to its dividend payout. Therefore, the distribution of dividend does not make any difference for the capital market. The shareholders of a firm are always interested in the profitability of firm. The confidence of shareholders is boosted up due to high profitability of the firm. They feel encouraged to invest in shares of the companies having stable earnings. The shareholders are also interested to know about the earnings of the company as they hope to receive dividend if company is earning healthy profits (Kasanen, Kinnunen and Niskanen, 1999). The managers are often found involved in earnings management to generate a signal to the shareholders. The discussion about the relationship of dividend and earnings was started from the work of Lintner (1956). The managers report their earnings to make the adjustments in dividends. Moreover, the stock prices of a company are not directly manipulated by its executives; rather they conduct earnings management practices 
which in turn affect stock prices (Lindstädt \& Seifert, 2006). It is strongly required to protect firms and shareholders from the prohibited and detrimental practices of balance sheet manipulation by management.

There are 54,606 limited companies in Pakistan. The total numbers of publicly listed companies are 609 . These companies operate in 32 different sectors. Pakistan is one of the countries where concentration of wealth is the main issue (SECP, 2010). All the top business men tend to explore the business opportunities where they can control and lead the matters for their own benefits. This resulted in formation of business ventures where family owned entities emerged largely on market screen. In this way, they can appropriate major chunk of profits to invest in the business again and thus dividend payouts are reduced to lower level. Financial managers control the financial affairs with the objective to arrange more and more funds for investment opportunities instead of drawing out profits in shape of dividend, on direction of their top management. This in turn bring positive results for family owned businesses where they can use profits for investment and make company's financial position more strong (Ahmed \& Javed, 2009).

Most of the shareholders in Pakistani companies are family members. The board of directors is also comprised of family member in mostly. Therefore, nepotism is very common in Pakistani companies because of this factor. The directors are given huge salaries with extra benefits (e.g. furnished houses, top of the model car, children's educational expenses and medical facilities etc.) that take the major chunk of company's earnings. All this reduces the net accounting profit of the company, which leads to a low dividend payout ratio. The minority shareholders may suffer as a result of this situation. Mehar (2007) stated that as a result of these problems, many of the investors prefer to establish their own companies instead of investing in other companies. Despite of the massive work on dividend policy, the researchers could not reach at a consensus. Most of the empirical models do not fit the data, so they have a poor predictability. A lot of further research is required to reach at a consensus. The current study is also an effort to contribute in this regard.

The current study has twofold significance. At one end, it will educate the investors and management practitioners about the existence of earnings management in Pakistani companies. On the other end, it will also analyze whether the purpose of earnings management is the dividend policy or otherwise. It is a question for practitioners and investors that either earnings management is for avoidance or announcement of the dividend payment. This study has four key objectives: (i) to investigate the existence of earnings management in Pakistani companies, (ii) to analyze the impact of earnings management on dividend policy, (iii) to examine the impact of organizational size on dividend policy, and (iv) to examine the role of ROE in dividend policy formulation.

\section{Literature Review}

This section explains the dividend policy, earnings management and their relation in the light of the previous studies. The findings of the previous studies and view of different researchers have been discussed in this section to have a broader understanding of dividend policy and its relationship with earnings management.

Dividend policy: It is a big challenge for a financial manager to develop a competent dividend policy. This policy should be helpful in increasing the confidence of shareholders, and should also be in the best interest of the company. Lintner (1956) is one of the pioneers who worked on dividend policy. He investigated how corporate managers arrive at the dividend policy. He uncovered that a dividend rate already prevails that act as a bench mark for the management. It is very complex decision for the management to reduce dividends. Some firms do not pay dividends in their early life cycle, because at that time they are focusing on growth and retaining their earnings. According to Miller \& Modigliani (1961), dividend policy is not relevant when capital markets are assumed to be perfect. Lately, researchers support this evidence like the study conducted by Litzenberger \& Ramaswamy (1979) showed that dividend policy is relevant if there is presence of market imperfections.

The company's transaction costs would be high for lower agency costs when the chances of dividend distribution are high (Jensen \& Meckling, 1976). The study of Rozeff (1982) is in line with the Jensen \& Meckling (1976) agency theory that companies decide their dividend to reduce the figure of agency and transaction costs related to the recently issued equity. The factors like profitability, debt ratio, growth 
opportunities, business risk, institutional ownership, and firm size cause variation in dividend payments (AlNajjar, 2009). Though better the news, the more will be the dividend (Bhattacharyya, 2007). The signaling dividend hypothesis declared that dividend policy provides an indicator about the current performance of the firm and its future prophecy (Fairchild, 2010). The free cash-flow hypothesis indicates that agency problems among managers and investors are represented by dividend policies (Easterbrook, 1984).

Fuller \& Thakor (2002) scribbled down that signaling and free cash flow hypothesis hold much (but not all) of the empirical evidence that increase (decrease) in dividend is good (bad) news, leading to stock price increases (decreases). The managers of listed firms use cash dividends to report firm's future performance (Lee \& Xiao, 2003). The changes in dividend report information about the profitability and indicate about company's future performance (Hussainey \& Aal-Eisa, 2009). In many of the developing countries like Pakistan, dividend payout ratio is not high enough as compared to the emerging economies (Mehar, 2007).

The investors will pay a premium for those companies who have stable dividends and reprimand firms that reduce dividends (Guttman et al., 2008). These findings support the study of Healy \& Palepu (1988). There are two important factors of dividend policy i.e. Reluctance to dividend reduction and level of future earnings (Bancel, Bhattacharyya, \& Mittoo, 2005). According to Brown \& Caylor (2006), independent audit committees are the key element of quality corporate governance and have a significant relationship with dividend yield. There is a positive and significant relationship among the firm performance and quality of corporate governance (Javed \& Iqbal, 2007). The stock prices of a company are positively associated with its dividend policy (Asquith \& Mullins, 1983). The stock prices show an increasing trend when there are chances of repurchase (Dann (1981; Vermaelen, 1984; Koch \& Shenoy, 1999).

Dividend policy of the company shows that to what extent a company will retain its earnings for future investments and to what extent it announces its earnings as a dividend (Goshen, 1995). Retained earnings are the amount of financing which a company can use without facing competition from other company's in the capital market. Dividend policy depicts the degree to which a company can avoid the examination of investors in the capital markets. Some of the inept managers try to avoid their performance analysis by announcing fewer dividends, thereby escaping from the external competition. The signaling model by Bhattacharya (1979) proposed that managers select dividend payment levels to provide information to market investors.

When market price of the company's stock is below intrinsic value, managers are motivated to generate a signal of this private information to investors. The dividend announced by the company increase the liquidation value of the shares which leads to more firms future earnings (Bhattacharya, 1979). Incremental dividend creates positive signal to the firm's performance and its future cash flows. The firms paying high dividend move towards the prosperity and increased level of profitability.

Earnings Management: Earnings management is most highlighting and key issue for the researchers since 1980s. It is an action of accounting. The use of accounting alternatives to adjust the earnings which have been reported by managers for their benefits is termed as earnings management. Extensive literature supports that managers can strongly affect reported earnings (Jensen \& Murphy, 1990; Bushman \& Indejejikian, 1993; Sloan, 1993; Carpenter \& Remmers, 2001; Sloan, 2001). Graham, Harvey \& Rajgopal (2005) found in their survey that there are five conventional practices of earnings management. These practices include: (i) production changes, (ii) timing for the sale of fixed assets to affect gains and losses, (iii) increase in rate of sales tax and price discounts to adjust revenue, (iv) amendment in the schedule of shipments, and (v) the opportunistic reduction of research and development expenses.

The value of a company is fostered by an increase in earnings. The earnings is managed to recuperate shortfall of a company (Hayn, 1995). Liu \& Tseng (2004) conducted a study on association between earnings management and dividend policy. They used cash dividend payout ratio as a test variable and discretionary accruals as a proxy for earnings management. The results of their study revealed the fact that companies having low payout ratio, have more chances of discretionary accrual, which is a measure of earnings management. The earnings management is strongly motivated by agency gaps between shareholders and outside investors (Liu \& Lu, 2004). Corporate governance is the tool to demote earnings management practices. Poor corporate governance creates agency problem which is also a cause of earnings management. It is recommended to pay the share of shareholders in terms of dividend to avoid the agency problem (Shah, 
Yuan \& Zafar, 2010). Huai-dong (2000) stated that to reduce earnings management, it is important to enhance corporate governance practices.

Dividend Policy and Earnings Management: There is a strong association flanked by dividend policy and earnings of the company. The idea of dividend impelling earnings management was first studied by Kasanen et al., (1999). According to their findings, high returns have been demanded by the shareholders, expecting the smooth dividend gush. Therefore, the companies are encouraged for earnings management to exhibit sufficient income to pay dividend. The study of Kato, Kunimura \& Yoshida (2001) found some evidences on the dividend stimulated earnings management. They also divulged the fact that banks manage their earnings to stay on top.

The expectations of shareholders to receive dividend also increases, as a result of increase in reported earnings. For the managers, dividend is a real hurdle so that they manage to show fewer earnings. The managers can manipulate their earnings to manage regulatory restriction of paying dividend (Edelstein et al, 2008). They can show less income and more expenses to fulfill this objective. The study of Edelstein et al. (2008) supports the findings of Kato et al. (2001) who revealed dividend stirred earnings management, but contradictory with the study of Savov (2006) who found in his study that firms holding more investments have more chances of discretionary accruals in their earnings. These discretionary accruals are the measure of earnings management. Conversely, earnings management practices and investments are found negatively related to dividend payouts. Kumar \& Lee (2001) stated that there is a systematic connection among stock prices and unpredicted changes in dividend. This connection establishes different dividends models through which managers devise their strategies to signal the earning prospects of the company. Most of the previous researchers (Fama \& Babiak, 1968; Brickley, 1983; Aharony \& Dotan, 1994; Kumar \& Lee, 2001) use the Lintner's (1956) work to evaluate the dividend policy. Lintner (1956) presented a model of partial adjustment of dividends. His model was proposed for the smoothing of dividend. The important implication of his model is that dividend is continually adjusted with respect to stochastic variation in earnings.

Garret \& Priestley (2000) assumed that there is always a target dividend level toward which managers make all the adjustments. Their model of dividend behavior suggested that target dividend is a function of lagged stock prices and earnings. They empirically proved that dividends signal the shock to the current earnings, but they rejected the notion that dividends signal anything about the future earnings. The changes in annual dividends and earning move together but there is weak evidence that the information regarding future earnings can be disseminated by the dividends (Foerster \& Sapp, 2006). However, there is a great support for the signaling impact of dividend by many researchers (Kalay \& Lowenstein; 1986; Healy \& Palepu, 1988; Aharony \& Dotan, 1994). According to Shah et al., (2010) earnings management does not have any relation with the dividend announcement. It is still a controversial issue that dividends signal about permanents earnings of the company. This issue needs a lot of further investigation.

The researchers (Brickley, 1983; Healy \& Palepu, 1988; Aharony \& Dotan, 1994) have provided empirical evidences that earnings are directly proportional to dividends. Any increase in the current dividends will lead to an increase in future earnings of the company. This notion has been rejected by many researchers (Garret \& Priestley, 2000). The literature suggests that dividends and earnings are interrelated. Researchers have proven that dividends have a signaling power about the future earnings of the company (Aharony \& Dotan, 1994; Kumar \& Lee, 2001) and earnings can also predict about the future dividends announced by the firm (Fama \& Babiak, 1968; Miller \& Rock, 1985).

\section{Hypotheses}

$\mathrm{H}_{1}$ : Dividend policy is not associated with earnings management.

$\mathrm{H}_{2}$ : ROE is positively associated with dividend payment.

$\mathrm{H}_{3}$ : Larger companies pay higher dividends.

\section{Methodology}

This section explains the research methodology employed to examine the relationship between earnings management and dividend policy. 
Sample: The sample of 86 listed companies on KSE is taken in this study to explore the relationship between dividend policy and earnings management. We have used the convenience sampling technique for data collection. We have included only non financial companies in this study from different sectors. Data is collected from the SBP's Balance Sheet Analysis, website of Business recorder, and as well as from the annual reports of the companies.

Estimation of Earnings Management: Extensive literature has used discretionary accruals as the proxy of earnings management. There are several methods to calculate these accruals, which include The Healy Model (1985), The Jones Model (1991) and Modified Jones Model (1995). The latest model is Modified Cross Sectional Jones Model (1995). Difference between the total accruals and non discretionary accruals is known as Discretionary accruals. Firstly, we have calculated total accruals. The literature provides two key approaches for this purpose i.e. balance sheet approach and cash flow statement approach.

Balance Sheet Approach: According to this approach, Healey (1985) and Jones (1991) employed the following formula to compute total accruals:

$\mathrm{TA}_{\mathrm{it}}=\Delta \mathrm{CA}_{\mathrm{it}}-\Delta \mathrm{Cash}_{\mathrm{it}}-\Delta \mathrm{CL}_{\mathrm{it}}+\Delta \mathrm{DCL}_{\mathrm{it}}-\mathrm{DEP}_{\mathrm{it}}$

Where:

$\Delta \mathrm{CA}_{\mathrm{it}}=$ Change in current assets in year $\mathrm{t}$

$\Delta$ Cash $_{\text {it }}=$ Change in cash and cash equivalents in year $\mathrm{t}$

$\Delta \mathrm{CL}_{\mathrm{it}}=$ Change in current liabilities in year $\mathrm{t}$

$\triangle \mathrm{DCL}_{\mathrm{it}}=$ Change in debt included in the current liabilities in year $\mathrm{t}$

$\mathrm{DEP}_{\mathrm{it}}=$ Depreciation and amortization expense in year $\mathrm{t}$

Cash Flows Statement Approach: This is the second approach to calculate total accruals which is easy to calculate.

$\mathrm{TA}_{\mathrm{it}}=\mathrm{NI}_{\mathrm{it}}-\mathrm{CFO}_{\mathrm{it}}$

Where:

$\mathrm{TA}_{\mathrm{it}}=$ Total accruals in year $\mathrm{t}$ for organization $\mathrm{i}$

N.I $\mathrm{I}_{\text {it }}=$ Net Income in year $\mathrm{t}$ for organization i

$\mathrm{CFO}_{\mathrm{it}}=$ Cash flows from operating activities in year $\mathrm{t}$ for organization $\mathrm{i}$

We have followed cash flow statement approach in this study because of its simplicity. Non-discretionary accruals have been calculated as follows:

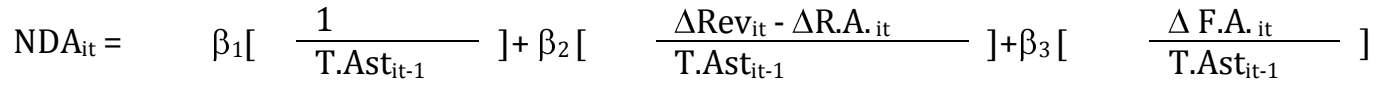

Where, NDA is non discretionary accruals, $\Delta$ Rev is change in revenue in year $t, \Delta R$.A. is change in Receivables, T. Ast ${ }_{-1}$ is total assets in year $t_{-1}, \Delta$ F.A. is change in fixed assets in year $t$, whereas $\beta_{1}$ and $\beta_{2}$ are the respective coefficients and $\alpha$ is intercept. After computing total accruals and non-discretionary accruals, we have used the following equation to find out discretionary accruals:

$\mathrm{DA}_{\mathrm{it}}=\mathrm{TA}_{\mathrm{it}}-\mathrm{NDA}_{\mathrm{it}}$

Where:

$\mathrm{TA}_{\mathrm{t}}=$ Total Accruals

$\mathrm{NDA}_{\mathrm{t}}=$ Non-Discretionary Accruals,

$\mathrm{DA}_{\mathrm{t}}=$ Discretionary Accruals

Common Effect Model: We have used the common effect model in panel data analysis to test the research hypothesis.

$\mathrm{DPO}_{\mathrm{it}}=\alpha+\beta_{1} \mathrm{DA}_{\mathrm{it}}+\beta_{2} \mathrm{ROE}_{\mathrm{it}}+\beta_{3} S_{\mathrm{it}}+\varepsilon_{\mathrm{it}}$

Where:

DPO = Dividend Payout

DA = Discretionary Accrual

ROE = Return on Equity

$\mathrm{S}=$ Size of Company (Total Assets) 


\section{Results and Discussion}

This section provides the results of statistical tests applied to the collected data and discussion in the light of the obtained results.

Table 1 shows the descriptive statistics for all the variables. The table depicts the values of mean, standard error, standards deviation and variance for all the variables.

Table 1: Descriptive Statistics

\begin{tabular}{lclll}
\hline & DPO & D.A. & ROE & Size \\
\hline Mean & 0.48359 & 0.21759 & 0.10069 & 8.06060 \\
Median & 0.08577 & 0.05786 & 0.15071 & 8.11284 \\
Standard Deviation & 2.02844 & 0.82837 & 1.16658 & 1.91330 \\
Count & 430 & 430 & 430 & 430 \\
\hline
\end{tabular}

The mean values for DPO, DA, ROE and Size are $0.48359,0.21759,0.10069$ and 8.0606 respectively. The values of median for DPO, DA, ROE and size are 0.08577, 0.05786, 0.15071 and 8.11284. DPO has a larger standard deviation as compared to other variables i.e. 2.02844. The size has the $2^{\text {nd }}$ high standard deviation of 1.91330. ROE has a standard deviation of 1.91330 and D.A. has a standard deviation of .82837 .

We have also checked the multi-colinearity among the variables by applying the correlation. Table 2 is showing the correlation matrix. Correlation matrix is showing that all the variables are not highly correlated with each other. This low correlation among the variables negates the presence of multi-colinearity in among the independent variables.

After applying the correlation and proving the non-presence of multi-colinearity in the data, we have applied regression to test our statistical hypothesis. Table 3 is showing the summary of the regression statistics. The value of $R$ i.e. simple relationship among the variables is 0.37724 . The value of $R^{2}$ is 0.14231 that means there is only $14.231 \%$ variation caused by the independent variables in dividend payout ratio. The adjusted $R^{2}$, a better measure than $R^{2}$, has a lesser value of 0.13627 i.e. $13.627 \%$.

Table 2: Correlation Matrix

\begin{tabular}{lllll}
\hline & Dividend & D.A. & ROE & Size \\
\hline Dividend & 1 & & & \\
D.A. & -0.01119 & 1 & & \\
ROE & 0.00839 & 0.04758 & 1 & \\
Size & -0.37506 & 0.07723 & 0.07620 & 1 \\
\hline
\end{tabular}

Table 3: Regression Summary Statistics

\begin{tabular}{ll}
\hline Regression Statistics & \\
\hline Multiple R & 0.37724 \\
R Square & 0.14231 \\
Adjusted R Square & 0.13627 \\
Standard Error & 1.88518 \\
Observations & 430 \\
\hline
\end{tabular}

Table 4, the anova table, is providing the value of $F$-test for the null hypothesis that none of the factors of earnings management is related to dividend payout ratio, or in other words that $R^{2}$ is zero. The null hypothesis is rejected here $(F(3)=23.56080, p<0.05)$, and it is concluded that at least one of the factors of earnings management is related to dividend payout ratio. The model fitness is authenticated as $p<0.05$. 
Table 4: Anova Table for Model Fitness

\begin{tabular}{llllll}
\hline & $\boldsymbol{d} \boldsymbol{f}$ & SS & MS & $\boldsymbol{F}$ & Significance $\mathbf{F}$ \\
\hline Regression & 3 & 251.19780 & 83.73260 & 23.56080 & 0.00000 \\
Residual & 426 & 1513.95915 & 3.55389 & & \\
Total & 429 & 1765.15694 & & & \\
\hline
\end{tabular}

Table 5 is the coefficient table that shows the estimate of regression coefficients. Standard errors of the estimates, $t$-tests and $p$ values are also given in table 5 .

Table 5: Coefficients Table

\begin{tabular}{lllll}
\hline & Coefficients & Standard Error & $\boldsymbol{t}$-Stat & $\boldsymbol{p}$-value \\
\hline Intercept & 3.70818 & 0.39469 & 9.39517 & 0.00000 \\
D.A. & 0.04005 & 0.11030 & 0.36308 & 0.71673 \\
ROE & 0.06347 & 0.07832 & 0.81042 & 0.41815 \\
Size & -0.40192 & 0.04784 & -8.40123 & 0.00000 \\
\hline
\end{tabular}

The estimated regression coefficients are given under the heading of "Coefficients". These give, for each of the independent variables, the predicted change in the dependent variable when the independent variable is increased by one unit conditional on all the other variables in the model remaining constant. The table 5 is showing that there would be $4.05 \%$ variation in dividend payout ratio, caused by Discretionary Accruals. However, this relationship is not very much significant as $p>0.05$. The $t$ statistic for this coefficient is 0.36308 i.e. not significant. So we accept our hypothesis that there is no association between the earnings management and dividend payout ratio.

The coefficient of ROE is 0.06347 i.e. showing $6.347 \%$ variation in dividend caused by ROE. Its $t$-statistics is 0.81042 i.e. insignificant. So we reject the second hypothesis. Higher ROE does not mean that shareholder's will receive higher dividend. The coefficient of size is -0.40192 . The negative relationship is showing that larger companies pay fewer dividends as compared to the smaller companies. This relationship is significant as $t$-statistics is -8.40123 and $p<0.0001$. On the basis of these results $\mathrm{H}_{3}$ is rejected. These results are in contradiction with Shah et al., (2010).

The results of common effect model show that there is a positive relationship between dividend payout ratio and discretionary accruals. These results are in line with the results of previous studies (Brickley, 1983; Healy \& Palepu, 1988; Aharony \& Dotan, 1994) and contradictory with the results of Savov (2006), who showed that there is a negative relationship between dividend policy and earnings management. However, this relationship is insignificant which does not authenticate the notion that managers are involved in earnings managemnet to make the adjustments in dividident payout. These results are in line with Shah et al., (2010), but in contradiction with Edelstein et al., (2008) who said that managers manipulate their earnings for making adjustment in dividend payout. It can be concluded from these results that the motive behind the earnings management is not the avoidance of dividend only. There could be number of other reasons for the earnings management.

The relationship of ROE is also insignificant with dividend payout. It is explained in introductory part of this study that most of companies in Pakistan are family owned. Therefore, the dividend payout ratio is not high enough despite the company is earning healthy profits. This notion has been proved by the insignificant relationship of ROE with dividend payout. This proves that most of the profit is retained for future use. This policy can be helpful in stressed market conditions when financing is not very easy. However, minority shareholders may suffer due to this restrictive dividend payout policy. 


\section{Conclusion}

This paper hypothesizes that earnings management in Pakistani listed companies is not associated with dividend payout. To provide supporting evidence, we conducted empirical analyses by using common effect model. On the basis of findings of this study, we have concluded the same that discretionary accruals do not significantly influence dividend policies. It means that the practices of earnings management are not only for the sake of dividend avoidance, but there can be several other reasons for this manipulation. The investors, while making investments decisions with a hope to have dividend, should not focus on the earnings management as a signal for the dividend policy formulation. There could be other motive behind the earnings management and not the dividend policy. The literature shows that this manipulation is performed possibly to cover the shortfall of a company. Similarly, ROE has not any significant relationship with dividend payout.

Further results revealed that there is a positive relationship between small companies and dividend payment. This shows that if size of the firm increases then dividend payout will decrease and vice versa. It can be concluded that small companies may pay higher dividends in order to attract more investors. However, this policy may be detrimental for the small companies. They might be paying dividends at the times when it is not suitable to pay. The companies need to review their policy at these times. These companies need to focus more on retained earnings than payment of dividends. Otherwise the company will have to rely more on debt financing, creating a solvency risk.

Limitations and Recommendations for Future Researchers: The current study has been conducted on a small sample size i.e. 2004-2009. The future research can be carried out on a more informative sample.

- The present study is not focusing on sectoral differences of earnings management and dividend policy. The future research can be conducted while taking these differences in consideration.

- The future research can also be conducted to make a comparison between the financial and nonfinancial companies.

- This study shows that small companies are paying higher dividends but usually it is always more risky to invest in small companies. The future research can be conducted to analyze the involved risk in the companies.

- A cross country analysis can also be performed to have a broader understanding of the relationship between earnings management and dividend policy.

\section{References}

Aharony, J. \& Dotan, A. (1994). Regular dividend announcements and future unexpected earnings: An empirical analysis. Financial Review, 29(1), 125-151.

Ahmed, H. \& Javed, A. (2009). Dynamics and determinants of dividend policy in Pakistan: Evidence from Karachi stock exchange non-financial listed firms. International Research Journal of Finance and Economics , 25, 148-171.

Al-Najjar, B. (2009). Dividend behaviour and smoothing new evidence from Jordanian panel data. Studies in Economics and Finance, 26(3), 182-197.

Asquith, P. \& Mullins, D. W. (1983). The impact of initiating dividend payments on shareholder wealth. Journal of Business, 56(1), 77-96.

Bancel, F., Bhattacharyya, N. \& Mittoo, U. R. (2005). Cross-country determinants of payout policy: A survey of European firms. SSRN Working Paper, Available at SSRN: http://ssrn.com/abstract=683111.

Bhattacharya, S. (1979). Imperfect information, dividend policy, and the bird in the hand" fallacy. The Bell Journal of Economics, 10(1), 259-270.

Bhattacharyya, N. (2007). Dividend Policy: A Review. Managerial Finance, 13(1), 4-13.

Black, F. (1976). The dividend puzzle. Journal of Portfolio Management, 2(2), 5-8.

Brickley, J. A. (1983). Shareholder wealth, information signaling, and the specially designated dividend: An empirical study. Journal of Financial Economics, 12(2), 187-209.

Brown, L. D. \& Caylor, M. L. (2006). Corporate governance and firm valuation. Journal of Accounting and Public Policy, 25, 409-434. 
Bushman R. M. \& Indejejikian, R. J. (1993). Accounting income, stock price, and managerial compensation. Journal of Accounting and Economics, 16(1-3), 3-23.

Carpenter J. N., Remmers, B. (2001). Executive Stock Option Exercises and Inside Information. The Journal of Business, 74(4), 513-534.

Dann, L. (1981). Common stock repurchases: An analysis of returns to bondholders and stockholders. The Journal of Financial Economics, 9(2), 113-138.

Edelstein, R. H., Liu, P. \& Tsang, D. (2009). Real Earnings management and dividend payout signals: A study for U.S. real estate investment trusts. (CAAA) 2008 Annual Conference Paper. Available at SSRN: http://ssrn.com/abstract=1079984.

Easterbrook, F. H. (1984). Two agency-cost explanations of dividends. The American Economic Review, 74(4), 650-659.

Fairchild, R. (2010). Dividend policy, signalling and free cash flow: an integrated approach. Managerial Finance, 36(5), 394-413.

Fama, E. F. \& Babiak, H. (1968). Dividend policy: An empirical analysis. Journal of the American Statistical Association, 63(324), 1132-1161.

Foerster, S. \& Sapp, S. G. (2006). The changing role of dividends: A firm-level study from the nineteenth to the twenty-first century. The Canadian Journal of Economics, 39(4), 1316-1344.

Fuller, K. \& Thakor, A. (2002). Signaling, free cash flow, and 'non-monotonic' dividends. AFA 2003 Washington, DC Meetings. Available at SSRN: http://ssrn.com/abstract=343980

Garret, I. \& Priestley, R. (2000). Dividend behavior and dividend signaling. The Journal of Financial and Quantitative Analysis, 35(2), 173-189.

Goshen, Z. (1995). Shareholder dividend options. The Yale Law Journal, 104(4), 881-932.

Graham, J. R., Harvey, C. \& Rajgopal, S. (2005). The economic implications of corporate financial reporting. Journal of Accounting and Economics, 40(1-3), 3-73.

Guttman, I., Kadan, O. \& Kandel, E. (2008). A theory of dividend smoothing. Available at SSRN: http://ssrn.com/abstract $=1012675$

Hayn, C., (1995). The information content of losses. Journal of Accounting and Economics, 20(2), 125-153.

Healy, P. \& Palepu, K. (1988). Earnings information conveyed by dividend initiations and omissions. Journal of Financial Economics, 21(2), 149-175.

Huai-dong, W. (2000). Empirical analysis on related transaction earnings management of listed companies. Available at http://www.seiofbluemountain.com/upload/product/200911/2009cyjdhy4z2a5.pdf.

Hussainey, K. \& Aal-Eisa, J. (2009). Disclosure and dividend signalling when sustained earnings growth declines. Managerial Auditing Journal, 24(5), 445-454.

Javed, A. \& Iqbal, R. (2007). The Relationship between corporate governance indicators and firm value: A case study of Karachi stock exchange. PIDE Working Papers, Available at http://mpra.ub.unimuenchen.de/2225/1/MPRA_paper_2225.pdf.

Jensen, M. C. \& Meckling, W. H. (1976). Theory of the firm: managerial behavior, agency costs and wwnership structure. Journal of Financial Economics, 3(4), 305-360.

Jensen, M. C. \& Murphy. K. J. (1990). Performance pay and top-management incentives. The Journal of Political Economy, 98(2), 225-264.

Jones, J. (1991). Earnings management during import relief investigations. Journal of Accounting Research, 29, 193-228.

Kalay, A. \& Lowenstein, U. (1986). The Informational Content of the timing of dividend announcements. Journal of Financial Economics, 16(3), 373-388.

Kasanen, E., Kinnunen, J. \& Niskanen, J. (1999). Dividend-based earnings management: Empirical evidence from Finland. Journal of Accounting and Economics , 22(1-3), 283-312.

Kato, K., Kunimura, M. \& Yoshida, Y. (2001). Banks' Earnings Management before Potential Violation of Dividend Regulation in Japan. Economic Working Paper 238. Available at SSRN: http://ssrn.com/abstract=273945.

Koch, P. D. \& Shenoy, C. (1999). The information content of dividend and capital structure policies. Financial Management, 28(4), 16-35.

Kumar, P. \& Lee, B. S. (2001). Discrete Dividend Policy with Permanent Earnings. Financial Management, $30(3), 55-76$.

Lee C. J. \& Xiao X. (2003). Cash dividend and large shareholder expropriation in China. European Financial Management Association 2003 Annual Meeting. Finland. 
Lindstädt, H. \& Seifer, C. (2006). A significant interrelation between balance sheet manipulation and stock option remuneration. An empirical study of us companies. Problems and Perspectives in Management, 1, 72-85.

Lintner, J. (1956). Distribution of incomes of corporations among dividends, retained earnings, \& taxes. American Economic Review, 46(2), 97-113.

Litzenberger, R. H. \& Ramaswamy, K. (1979). The effect of personal taxes and dividends on capital asset prices. The Journal of Financial Economics, 7(2), 163-195.

Liu, Q. \& Lu, J. Z. (2004). Earnings management to tunnel: Evidence from China's listed companies. EFMA 2004 Basel Meetings Paper, Available at SSRN: http://ssrn.com/abstract=349880.

Liu, L-L. S. \& Tseng, S-Y. (2004). The association between dividend policy and earnings management. Available at http://aaahq.org/midwest/Meeting\%20Info/2007/Abstracts /2A-3.pdf.

Mehar, D. A. (2007). Corporate governance and dividend policy. Retrieved from http://mpra.ub.unimuenchen.de/619/.

Miller, M. H. \& Rock, K. (1985). Dividend policy under asymmetric information. Journal of Finance, 40(4), 1031-1051.

Miller, M. \& Modigilani, F. (1961). Dividend policy, growth, and the valuation of shares. The Journal of Business, 34(4), 411-433.

Mittoo, F. B. (2005). Cross-Country Determinants of Payout Policy: A Survey of European Firms. Available at SSRN: http://ssrn.com/abstract $=683111$

Rozeff, M. S. (1982). Growth, beta, and agency costs as determinants of dividend payout ratios. The Journal of Financial Research, 5(3), 249-259.

Savov, S. (2006). Changes, signaling, and stock price performance. Available at SSRN: http://ssrn.com/abstract $=933082$.

SECP. (2010). Annual Report for the year 2009-10. Islamabad: Security and Exchange Commission of Pakistan.

Shah, S. Z., Yuan, H. \& Zafar, N. (2010). Earnings management and dividend policy: An empirical comparison between Pakistani listed companies and Chinese listed companies. International Research Journal of Finance and Economics, 35, 51-60.

Sloan, R. G. (1993). Accounting earnings and top executive compensation. Journal of Accounting and Economics, 16(1-3), 55-100.

Sloan, R. G. (2001). Financial accounting and corporate governance: a discussion. Journal of Accounting and Economics, 32(1-3), 335-347.

Vermaelen, T. (1984). Repurchase tender offers, signaling, and managerial incentives. Journal of Financial and Quantitative Analysis, 19(2), 163. 